\title{
KANDUNGAN GIZI, SIFAT FISIK, DAN TINGKAT PENERIMAAN ES KRIM KACANG HIJAU DENGAN PENAMBAHAN SPIRULINA
}

\author{
Hardaning Ausiea Marantha, Ninik Rustanti*) \\ Program Studi Ilmu Gizi Fakultas Kedokteran Universitas Diponegoro \\ J1.Dr.Sutomo No.18, Semarang, Telp (024) 8453708, Email : gizifk@ undip.ac.id
}

\begin{abstract}
Background : Iron deficiency anemia is a health problem that can be prevent by increasing iron intake through preferred products such as ice cream. In order to produce a low fat ice cream with high iron content, spirulina is being added in mung bean ice cream.

Objective : Analyze nutritional content (iron, protein, and fat), physical properties (overrun and melting rate), and acceptance level in mung bean ice cream with spirulina addition.

Method : This was an experimental study with randomization. There were four treatments $0 \%$ as control, $0.15 \%$, $0.30 \%$, and $0.45 \%$ spirulina addition in mung bean ice cream. Iron, protein, fat content, and overrun were analyzed by using one way ANOVA followed by LSD test while melting rate and acceptance level were analyzed by using Kruskal wallis followed by Mann Whitney test.

Result : Mung bean ice cream with $0.45 \%$ spirulina contain the highest iron and protein $(5.730 \mathrm{mg} \%$ and $1.813 \%)$ also the lowest fat (0.204\%). Mung bean ice cream with $0.15 \%$ spirulina addition has the highest overrun and melting rate (19.68\% and $0.5 \mathrm{ml} / \mathrm{minute})$. Mung bean ice cream with $0.15 \%$ spirulina has the highest acceptance level among other mung bean ice cream with spirulina addition.

Conclusion : Spirulina addition increased iron and protein also influenced fat content in mung bean ice cream (significant). But spirulina addition decreased overrun in mung bean ice cream. Spirulina addition influence acceptance of color but decrease acceptance of taste significantly. Spirulina addition also decrease acceptance of aroma and texure in mung bean ice cream.
\end{abstract}

Keywords : ice cream; mung bean; spirulina; iron; low fat

\begin{abstract}
ABSTRAK
Latar Belakang : Anemia defisiensi besi dapat dicegah dengan meningkatkan konsumsi besi melalui produk yang disukai seperti es krim. Penambahan spirulina pada es krim kacang hijau diharapkan dapat menjadi alternatif produk tinggi besi dan rendah lemak.

Tujuan : Menganalisis kandungan zat gizi (kadar zat besi, protein, dan lemak), sifat fisik (overrun, melting rate), dan tingkat penerimaan es krim kacang hijau dengan penambahan spirulina.

Metode : Merupakan penelitian eskperimental rancangan acak lengkap satu faktor yaitu konsentrasi penambahan spirulina (0\% sebagai kontrol, 0.15\%, 0.30\%, dan 0.45\%) pada es krim kacang hijau. Analisis kadar zat besi, protein, lemak, dan nilai overrun diuji dengan one way ANOVA dilanjutkan dengan Least Significance Different (LSD), sedangkan analisis melting rate dan tingkat penerimaan menggunakan Kruskal wallis yang dilanjutkan dengan Mann Whitney.

Hasil : Es krim kacang hijau dengan penambahan $0.45 \%$ spirulina mengandung kadar zat besi dan protein tertinggi dengan kadar lemak terendah yaitu sebesar $5.730 \mathrm{mg} \%$, 1.813\%, dan 0.204\%. Es krim kacang hijau dengan penambahan $0.15 \%$ spirulina memiliki nilai overrun tertinggi sebesar $19.68 \%$ dan melting rate tertinggi $0.5 \mathrm{ml} / \mathrm{menit}$. Es krim perlakuan dengan tingkat penerimaan terbaik adalah es krim kacang hijau dengan penambahan spirulina $0.15 \%$.

Simpulan : Penambahan spirulina meningkatkan kadar zat besi dan protein serta mempengaruhi kadar lemak es krim kacang hijau secara signifikan. Namun penambahan spirulina menurunkan nilai overrun dan tidak mempengaruhi melting rate es krim kacang hijau secara tidak signifikan. Penambahan spirulina mempengaruhi nilai warna dan menurunkan nilai aroma secara signifikan serta menurunkan nilai tekstur, dan rasa es krim kacang hijau (tidak signifikan).
\end{abstract}

Kata kunci : es krim; kacang hijau; spirulina; zat besi; rendah lemak

\section{PENDAHULUAN}

Anemia merupakan permasalahan gizi global. Sebanyak $24,8 \%$ populasi dunia menderita anemia dengan prevalensi penderita anemia pada wanita usia 15-49 tahun sebesar 30.2\%. ${ }^{1}$ Laporan hasil Riset Kesehatan Dasar tahun 2013 menunjukkan prevalensi anemia yang diperkirakan sebagai anemia defisiensi zat besi di Indonesia pada wanita usia 15 - 49 tahun sebesar $22.7 \%$. $^{2}$

Anemia defisiensi besi merupakan tahap akhir dari defisiensi besi yang terjadi dalam waktu lama. Defisiensi zat besi dapat menimbulkan gangguan

\footnotetext{
*)Penulis Penanggungjawab
} 
respon imun sehingga mudah mengalami infeksi, gangguan konsentrasi karena kelelahan, dapat mempengaruhi kemampuan kognitif, dan gangguan perkembangan emosi. ${ }^{3-6}$ Defisiensi zat besi disebabkan konsumsi zat besi yang kurang dari kebutuhan. Salah satu alternatif cara untuk menambah asupan zat besi yaitu dengan meningkatkan kandungan zat besi pada suatu produk pangan yang banyak disukai seperti es krim.

Es krim merupakan produk beku hasil olahan susu, krim, dan kombinasi berbagai bahan yang disukai berbagai kalangan. Konsumsi es krim mengalami peningkatan dari tahun ke tahun. Pada tahun 2004, terjadi peningkatkan konsumsi es krim perkapita di Indonesia sebesar 67\% dibanding pada tahun $1999 .{ }^{7}$ Namun, produk es krim yang beredar di pasaran berupa es krim yang tinggi lemak dan rendah zat besi. Setiap 100 gram es krim mengandung $210 \mathrm{kkal}$ energi, $0.1 \mathrm{mg}$ zat besi, 4 gram protein, 12.5 gram lemak, dan 20.6 gram karbohidrat. ${ }^{8} \mathrm{Hal}$ ini menunjukkan perlu dilakukan modifikasi bahan penyusun pada es krim dengan menambahkan bahan tinggi protein dan zat besi seperti spirulina.

Spirulina merupakan ganggang hijau biru yang oleh US FDA dikategorikan sebagai makanan yang secara umum aman dikonsumsi atau Generally Recognized as Safe (GRAS). ${ }^{9}$ Spirulina digunakan sebagai suplemen makanan karena kandungan gizinya yang tinggi. Setiap 100 gram spirulina kering mengandung 57.47 gram protein, 7.72 gram lemak, dan $28.5 \mathrm{mg}$ zat besi. ${ }^{10}$ Zat besi pada spirulina memiliki bioavailabilitas tinggi. Tikus yang diberi spirulina menyerap zat besi $60 \%$ lebih banyak dibanding tikus yang diberi suplementasi zat besi. ${ }^{11}$ Hal ini disebabkan karena zat besi dan mineral lain pada spirulina membentuk kompleks terlarut dengan pigmen biru phycocyanin selama proses pencernaan. ${ }^{11,12}$

Spirulina terbukti dapat mengatasi anemia. Pemberian 4 gram spirulina bubuk selama 30 hari pada wanita anemia hipokromik menunjukkan peningkatan hemoglobin darah sebesar $21 \%$ dari 10.9 menjadi $13.2 \mathrm{mg} \% .^{11}$ Selain meningkatkan hemoglobin darah, suplementasi spirulina juga merubah morfologi sel darah merah. Setelah pemberian 1 gram spirulina selama 50 hari, subjek dengan sel darah merah mikrositik hipokromik yang awalnya sebanyak $49.23 \%$ berkurang menjadi $24.6 \% .^{12}$

Penambahan spirulina bertujuan untuk meningkatkan kandungan mineral, protein, dan asam lemak esensial. Penambahan $0.3 \%$ bubuk spirulina pada es krim dapat meningkatkan kandungan zat besi sebesar $0.17 \mathrm{mg} / 100 \mathrm{ml}$ dan mineral sebesar $0.03 \% .^{13}$ Selain meningkatkan kandungan gizi, spirulina dapat meningkatkan nilai overrun dan menurunkan viskositas adonan es krim.

Untuk menghasilkan produk es krim yang rendah lemak, susu sapi yang merupakan bahan baku utama es krim dapat diganti dengan kacang hijau. Kacang hijau mengandung lemak sebesar $1,86 \% \cdot{ }^{14}$ Lemak pada kacang hijau terdiri dari $73 \%$ asam lemak tak jenuh dan $23 \%$ asam lemak jenuh. ${ }^{15}$ Rendahnya kandungan lemak menyebabkan aktivitas enzim lipoksigenase pada kacang hijau rendah sehingga hasil olahannya tidak mudah tengik. Kacang hijau mengandung protein sebesar $26.8 \%$ dengan daya cerna in vitro protein pada kacang hijau rebus sebesar $87.8 \% .^{14}$ Setiap 100 gram kacang hijau mengandung zat besi sebesar 7.9 gram $^{14}$ yang merupakan zat besi non heme.

Salah satu hasil olahan kacang hijau adalah susu kacang hijau. Beberapa penelitian menunjukkan proses perendaman, perebusan, dan pengupasan kulit dapat mengurangi bahkan menghilangkan zat anti nutrisi pada kacang hijau. ${ }^{14,16}$ Proses perendaman mengurangi tripsin inhibitor sebesar $15.8 \%$, tannin sebesar $39.4 \%$, dan asam fitat sebesar $26.7 \%$. Proses perebusan kacang hijau dapat menghilangkan tripsin inhibitor, mengurangi tannin sebesar $45.5 \%$, dan asam fitat sebesar $25.8 \% .^{14}$

Berdasarkan uraian di atas, dilakukan penelitian mengenai kandungan gizi (zat besi, protein, dan lemak), sifat fisik (overrun, melting rate) dan tingkat penerimaan es krim kacang hijau dengan penambahan spirulina.

\section{METODE}

Penelitian yang dilakukan merupakan penelitian dalam bidang food production. Penelitian dilaksanakan dari bulan Juni hingga Juli 2014 di laboratorium Teknologi Pangan Universitas Muhammadiyah Semarang.

Penelitian yang dilakukan merupakan penelitian eksperimental dengan rancangan acak lengkap satu faktor yaitu konsentrasi penambahan spirulina pada es krim kacang hijau. Terdapat 4 taraf perlakuan yaitu penambahan spirulina sebesar $0 \%$ sebagai kontrol $\left(\mathrm{T}_{0}\right), 0.15 \%\left(\mathrm{~T}_{1}\right), 0.30 \%\left(\mathrm{~T}_{2}\right)$, dan $0.45 \%\left(\mathrm{~T}_{3}\right)$ pada es krim kacang hijau. Persentase penambahan spirulina pada es krim kacang hijau ditentukan dari penelitian sebelumnya yang menyatakan penambahan spirulina bubuk sebesar $0.15 \%$ pada es krim memiliki nilai sensori yang baik. ${ }^{13}$ Setiap perlakuan dilakukan 3 kali ulangan yang dianalisis secara duplo untuk kandungan gizi, sedangkan uji tingkat penerimaan dilakukan satu kali tanpa pengulangan. 
Bahan baku yang dibutuhkan dalam pembuatan es krim kacang hijau dengan penambahan spirulina adalah kacang hijau, air, spirulina bubuk neoalgae, $15 \%$ gula pasir, $0.05 \%$ agar-agar swallow, dan $0.25 \%$ kuning telur. Pembuatan es krim kacang hijau diawali dengan pembuatan susu kacang hijau. Susu kacang hijau dibuat melalui proses sortasi, pencucian, perendaman, perebusan, penggilingan, penyaringan, dan pasteurisasi. Kemudian dilanjutkan dengan pembuatan es krim yang melalui proses pencampuran bahan, pasteurisasi, homogenisasi, pendinginan, penggunaan ice cream maker, dan pembekuan.

Data yang dikumpulkan meliputi kadar zat besi, kadar protein, kadar lemak, nilai overrun, nilai melting rate, dan tingkat penerimaan es krim kacang hijau dengan penambahan spirulina. Untuk mengetahui kandungan dari susu kacang hijau dilakukan uji kadar air, abu, protein, lemak, dan protein. Metode yang digunakan untuk analisis kadar zat besi menggunakan metode spektofotometri serapan atom (SSA), kandungan protein menggunakan metode mikro kjeldahl, dan kandungan lemak menggunakan metode soxhlet. ${ }^{17}$ Sifat fisik es krim yang diamati meliputi overrun yang dihitung menggunakan rumus persen overrun dan melting rate yang dihitung menggunakan rumus melting rate. ${ }^{18}$ Untuk mengetahui tingkat penerimaan es krim dilakukan uji hedonik dengan 5 skala kesukaan, yairu suka $=5$, agak suka $=4$, netral $=3$, tidak suka $=2$, dan sangat tidak suka $=1$. Uji ini dilakukan pada 25 panelis agak terlatih yaitu mahasiswi Program Studi Ilmu Gizi Universitas Muhammadiyah Semarang.

Uji normalitas menggunakan Shapiro-wilk dan uji variasi data dilakukan dengan Levene Test. Pengaruh penambahan spirulina terhadap kadar zat besi, protein, lemak, dan overrun es krim kacang hijau diuji menggunakan one way ANOVA dilanjutkan dengan uji Least Significance Different (LSD) pada derajat kepercayaan 95\%. Pengaruh penambahan spirulina terhadap melting rate dan tingkat penerimaan es krim kacang hijau diuji menggunakan Kruskal wallis yang dilanjutkan dengan uji Mann Whitney pada derajat kepercayaan $95 \%$.

\section{HASIL PENELITIAN Kandungan Gizi}

Hasil analisis data kandungan zat besi, protein, dan lemak es krim kacang hijau dengan penambahan spirulina dapat dilihat pada Tabel 1 .

Tabel 1. Kandungan Zat Besi, Protein, dan Lemak Es Krim Kacang Hijau dengan Penambahan Spirulina Per 100ml

\begin{tabular}{lccc}
\hline \multicolumn{1}{c}{ Jenis Perlakuan } & $\begin{array}{c}\text { Zat Besi }(\mathrm{mg} \%) \\
\text { Rerata } \pm \text { SD }\end{array}$ & $\begin{array}{c}\text { Protein }(\%) \\
\text { Rerata } \pm \text { SD }\end{array}$ & $\begin{array}{c}\text { Lemak }(\%) \\
\text { Rerata } \pm \text { SD }\end{array}$ \\
\hline Kontrol & $1.282 \pm 0.184^{\mathrm{c}}$ & $1.067 \pm 0.050^{\mathrm{d}}$ & $0.130 \pm 0.044^{\mathrm{c}}$ \\
Spirulina 0.15\% & $1.465 \pm 0.246^{\mathrm{c}}$ & $1.221 \pm 0.038^{\mathrm{c}}$ & $0.252 \pm 0.017^{\mathrm{a}}$ \\
Spirulina 0.30\% & $2.660 \pm 0.344^{\mathrm{b}}$ & $1.437 \pm 0.053^{\mathrm{b}}$ & $0.233 \pm 0.004^{\mathrm{ab}}$ \\
Spirulina 0.45\% & $5.730 \pm 0.186^{\mathrm{a}}$ & $1.813 \pm 0.032^{\mathrm{a}}$ & $0.204 \pm 0.006^{\mathrm{b}}$ \\
& $\mathrm{p}=0.000$ & $\mathrm{p}=0.000$ & $\mathrm{p}=0.001$ \\
\hline
\end{tabular}

Keterangan : Angka yang diikuti dengan huruf superscript $(\mathrm{a}, \mathrm{b}, \mathrm{c}, \mathrm{d})$ berbeda menunjukkan beda nyata

Kadar zat besi tertinggi terdapat pada es krim kacang hijau dengan penambahan $0.45 \%$ spirulina sebesar $5.730 \mathrm{mg} \%$. Penambahan spirulina meningkatkan kadar zat besi pada es krim kacang hijau secara signifikan $(\mathrm{p}=0.000)$. Namun, tidak ada beda nyata kadar zat besi pada es krim kacang hijau kontrol dan es krim kacang hijau dengan penambahan $0.15 \%$ spirulina.

Es krim kacang hijau dengan penambahan $0.45 \%$ spirulina mengandung kadar protein paling tinggi sebesar $1.813 \%$. Hasil analisa data menunjukkan penambahan spirulina meningkatkan kadar protein pada es krim kacang hijau secara $\operatorname{signifikan}(\mathrm{p}=0.000)$. Ada beda nyata pada semua kelompok perlakuan.

Kadar lemak pada es krim kacang hijau dipengaruhi oleh penambahan spirulina secara $\operatorname{signifikan}(\mathrm{p}=0.001)$. Kadar lemak tertinggi terdapat pada es krim kacang hijau dengan penambahan $0.15 \%$ spirulina sebesar $0.252 \%$.

\section{Sifat Fisik}

Hasil analisa sifat fisik es krim kacang hijau dengan penambahan spirulina meliputi overrun dan melting rate dapat dilihat pada Tabel 2 .

Tabel 2. Sifat Fisik Es Krim Kacang Hijau dengan Penambahan Spirulina

\begin{tabular}{lcc}
\hline \multirow{2}{*}{ Jenis Perlakuan } & $\begin{array}{l}\text { Overrun (\%) } \\
\text { Rerata } \pm \text { SD }\end{array}$ & $\begin{array}{c}\text { Melting Rate (ml/menit) } \\
\text { Rerata } \pm \text { SD }\end{array}$ \\
\hline Kontrol & $21.84 \pm 4.14$ & $0.493 \pm 0.006$ \\
\hline
\end{tabular}




\begin{tabular}{lcc}
\hline Spirulina $0.15 \%$ & $19.68 \pm 5.99$ & $0.500 \pm 0.019$ \\
Spirulina $0.30 \%$ & $15.09 \pm 2.90$ & $0.500 \pm 0.019$ \\
Spirulina $0.45 \%$ & $14.47 \pm 1.36$ & $0.496 \pm 0.035$ \\
& $\mathrm{p}=0.141$ & $\mathrm{p}=0.925$ \\
\hline
\end{tabular}

Es krim kacang hijau dengan penambahan spirulina memiliki nilai overrun yang lebih rendah dibandingkan es krim kacang hijau kontrol. Nilai overrun tertinggi pada es krim perlakuan terdapat pada es krim kacang hijau dengan $0.15 \%$ spirulina sebesar $19.68 \%$. Hasil uji statistik menunjukkan tidak ada pengaruh penambahan spirulina terhadap nilai overrun es krim $(\mathrm{p}=0.141)$.

Nilai melting rate es krim kacang hijau dengan penambahan spirulina lebih tinggi dibandingkan es krim kacang hijau kontrol. Es krim kacang hijau dengan melting rate tertinggi adalah es krim kacang hijau dengan penambahan $0.15 \%$ dan $0.30 \%$ spirulina sebesar $0.500 \mathrm{ml} /$ menit. Secara statistik penambahan spirulina tidak mempengaruhi melting rate es krim kacang hijau $(\mathrm{p}=0.925)$

\section{Tingkat Penerimaan}

Hasil analisa data tingkat penerimaan es krim kacang hijau dengan penambahan spirulina meliputi warna, aroma, tekstur, dan rasa dapat dilihat pada Tabel 3.

Tabel 3. Hasil Analisis Tingkat Penerimaan Es Krim Kacang Hijau dengan Penambahan Spirulina

\begin{tabular}{|c|c|c|c|c|c|c|c|c|}
\hline \multirow{2}{*}{ Jenis Perlakuan } & \multicolumn{2}{|c|}{ Warna } & \multicolumn{2}{|c|}{ Aroma } & \multicolumn{2}{|c|}{ Tekstur } & \multicolumn{2}{|l|}{ Rasa } \\
\hline & Rerata \pm SD & Ket. & Rerata \pm SD & Ket & Rerata \pm SD & Ket. & Rerata \pm SD & Ket. \\
\hline Kontrol & $2.96 \pm 0.889^{b}$ & Netral & $3.52 \pm 0.770$ & Suka & $3.40 \pm 0.913$ & Suka & $3.92 \pm 0.997^{\mathrm{a}}$ & Suka \\
\hline Spirulina $0.15 \%$ & $3.68 \pm 0.802^{\mathrm{a}}$ & Suka & $3.36 \pm 0.700$ & Suka & $3.36 \pm 0.952$ & Suka & $3.28 \pm 0.891^{b}$ & Suka \\
\hline Spirulina $0.30 \%$ & $3.68 \pm 0.802^{\mathrm{a}}$ & Suka & $3.04 \pm 0.935$ & Suka & $3.04 \pm 0.935$ & Suka & $3.16 \pm 0.850^{b}$ & Suka \\
\hline Spirulina $0.45 \%$ & $\begin{array}{c}2.64 \pm 0.952^{c} \\
p=0.000\end{array}$ & Netral & $\begin{array}{c}2.84 \pm 1.028 \\
p=0.079\end{array}$ & Netral & $\begin{array}{c}2.80 \pm 0.866 \\
p=0.103\end{array}$ & Netral & $\begin{array}{c}3.00 \pm 1.115^{b} \\
p=0.010\end{array}$ & Netral \\
\hline
\end{tabular}

Keterangan : Angka yang diikuti dengan huruf superscript (a, b, c, d) berbeda menunjukkan beda nyata

Hasil analisa menunjukkan penambahan spirulina mempengaruhi warna es krim kacang hijau $(\mathrm{p}=0.000)$. Es krim kacang hijau dengan penambahan $0.15 \%$ dan $0.30 \%$ spirulina disukai oleh panelis dengan nilai sebesar 3.68. Secara statistik tidak terdapat perbedaan warna pada es krim kacang hijau dengan penambahan $0.15 \%$ dan $0.30 \%$ spirulina.

Aroma es krim kacang hijau semakin tidak disukai seiring meningkatnya konsentrasi spirulina meskipun secara statistik tidak signifikan $(\mathrm{p}=0.079)$. Nilai aroma yang disukai pada es krim perlakuan adalah es krim kacang hijau dengan penambahan $0.15 \%$ spirulina dengan nilai sebesar 3.36 .

Tekstur es krim perlakuan yang paling disukai adalah es krim kacang hijau dengan penambahan $0.15 \%$ spirulina dengan nilai sebesar 3.36. Penambahan spirulina menurunkan nilai tekstur es krim kacang hijau meskipun tidak signifikan $(\mathrm{p}=0.103)$.

Penambahan spirulina menurunkan nilai rasa es krim kacang hijau $(p=0.010)$. Rasa es krim kacang hijau semakin tidak disukai seiring meningkatnya konsentrasi spirulina meskipun masih dalam kategori netral hingga suka. Nilai rasa tertinggi pada es krim perlakuan adalah es krim kacang hijau dengan penambahan $0.15 \%$ spirulina sebesar 3.28.

\section{PEMBAHASAN \\ Kandungan Gizi}

Penambahan spirulina meningkatkan kadar zat besi pada es krim kacang hijau secara signifikan. Kadar zat besi tertinggi terdapat pada es krim kacang hijau dengan penambahan $0.45 \%$ spirulina sebesar $5.73 \mathrm{mg} \%$. Meningkatnya kadar zat besi pada es krim yang mendapatkan penambahan spirulina dikarenakan spirulina mengandung 28,5 $\mathrm{mg}$ zat besi $/ 100 \mathrm{~g}$ dengan bioavailabilitas yang tinggi. Tingginya bioavailabilitas zat besi pada spirulina disebabkan karena zat besi dan mineral lain pada spirulina membentuk kompleks terlarut dengan pigmen biru phycocyanin selama proses pencernaan. ${ }^{11,12}$ Meningkatnya kadar zat besi pada es krim kacang hijau yang ditambahkan spirulina sesuai dengan penelitian sebelumnya di mana penambahan spirulina secara signifikan meningkatkan kandungan zat besi pada es krim. ${ }^{13}$

Es krim mengandung kadar zat besi yang rendah yaitu sebanyak $0.1 \mathrm{mg} \%{ }^{8}$ Penelitian mengenai karakteristik es krim menunjukkan setiap $100 \mathrm{ml}$ es krim mengandung $0.03 \mathrm{mg}$ zat besi. ${ }^{13} \mathrm{Jadi}$, penambahan spirulina dapat dijadikan alternatif untuk meningkatkan kadar zat besi pada es krim.

Asupan zat besi harian yang direkomendasikan untuk wanita usia 15-49 tahun sebesar 15-18 mg /hari. ${ }^{19}$ Es krim kacang hijau dengan penambahan $0.45 \%$ spirulina sebanyak 100 
g mengandung $5.730 \mathrm{mg}$ zat besi dapat memenuhi $31.8-38.2 \%$ rekomendasi asupan zat besi harian.

Kadar protein es krim kacang hijau dengan penambahan spirulina meningkat secara signifikan. Kadar protein tertinggi terdapat pada es krim kacang hijau dengan penambahan $0.45 \%$ spirulina sebesar $1.813 \%$. Meningkatnya kadar protein terjadi karena spirulina mengandung protein sebesar 57.47 g /100 g. Tingginya kadar protein spirulina diikuti dengan daya cerna yang tinggi karena spirulina memiliki dinding sel yang terdiri dari selulosa. ${ }^{11}$ Meningkatnya kadar protein pada es krim kacang hijau dengan penambahan spirulina sesuai dengan penelitian sebelumnya dimana penambahan spirulina meningkatkan kadar protein meskipun secara statistik tidak signifikan. ${ }^{13}$

Kadar protein tertinggi pada es krim kacang hijau dengan penambahan $0.45 \%$ spirulina sebesar $1.813 \%$ belum memenuhi standar mutu es krim (minimal 2.7\%). ${ }^{20}$ Untuk memenuhi standar mutu es krim dapat menambahkan sumber protein pada adonan es krim seperti susu skim, susu segar, atau protein isolat.

Es krim dengan penambahan spirulina memiliki kadar lemak yang lebih tinggi dibandingkan es krim kacang hijau kontrol. Kadar lemak tertinggi terdapat pada es krim kacang hijau dengan penambahan $0.15 \%$ spirulina sebesar $0.252 \%$. Terjadi penurunan kadar lemak seiring dengan meningkatkan konsentrasi spirulina. Hal ini tidak sesuai dengan penelitian sebelumnya, dimana kadar lemak semakin meningkat seiring bertambahnya konsentrasi spirulina. ${ }^{13}$ Hasil yang tidak sesuai ini dimungkinkan terjadi karena terjadi reaksi oksidasi lemak pada proses pembuatan dan persiapan sampel sebelum analisa. Reaksi oksidasi lemak merupakan reaksi yang terjadi pada lemak yang mengandung asam lemak tidak jenuh. ${ }^{21}$ Reaksi oksidasi lemak dipengaruhi oleh oksigen dan suhu. Pada proses pembuatan, adonan es krim dan spirulina terpapar oleh oksigen yang dapat memicu reaksi oksidasi lemak. Sebelum dilakukan analisis lemak, dilakukan pengeringan pada sampel. Diperkirakan suhu pengeringan terlalu tinggi sehingga menginisiasi reaksi oksidasi.

Es krim kacang hijau mengandung lemak yang lebih tinggi dibanding es krim kacang hijau kontrol karena spirulina mengandung $7.72 \mathrm{~g}$ lemak $/ 100$ g. Sebagian besar asam lemak pada spirulina merupakan asam lemak esensial seperti linolenic dan gamma linolenic acid (GLA). ${ }^{11}$

Es krim tanpa lemak (non fat ice cream) adalah es krim yang mengandung $\leq 0.5 \mathrm{~g}$ lemak setiap sajian. ${ }^{22}$ Produk es krim yang dihasilkan sudah memenuhi ketentuan es krim tanpa lemak.
Namun, rendahnya kadar lemak mempengaruhi sifat fisik dan tingkat penerimaan es krim.

\section{Sifat Fisik}

Nilai overrun adalah pengembangan volume es krim terhadap volume adonan mula-mula karena adanya udara yang terperangkap dalam es krim. Nilai overrun yang tinggi menunjukkan es krim memiliki tekstur yang lembut. ${ }^{18}$ Standar nilai overrun untuk es krim skala industri adalah sebesar $70-80 \%$, sedangkan skala rumah tangga sebesar 35 $-50 \% .{ }^{18}$ Es krim skala rumah tangga memiliki nilai overrun yang rendah karena pada proses pembekuan tidak didukung injeksi udara.

Produk es krim yang dihasilkan tidak memenuhi standar overrun skala rumah tangga. Hasil analisa menunjukkan penambahan spirulina tidak mempengaruhi nilai overrun es krim. Es krim kacang hijau dengan penambahan $0.15 \%$ spirulina memiliki nilai overrun terbaik pada es krim perlakuan sebesar $19.68 \%$.

Rendahnya nilai overrun pada produk yang dihasilkan dapat disebabkan oleh formulasi bahan dan proses pembuatan. Formulasi bahan es krim seperti lemak, protein, dan stabilizer mempengaruhi nilai overrun es krim. Es krim kacang hijau mengandung lemak yang rendah sehingga buih yang dihasilkan pada proses homogenisasi tidak stabil. Rendahnya jumlah udara yang terperangkap dalam es krim menyebabkan es krim memiliki tekstur yang keras. Penggunaan stabilizer dapat memperbaiki sifat buruk akibat kurangnya lemak dengan membentuk lapisan gel yang mengikat molekul air. ${ }^{18}$ Stabilizer yang digunakan pada penelitian ini adalah $0.05 \%$ agar-agar karena dapat membentuk lapisan gel yang kuat dengan konsentrasi rendah. Kekuatan gel yang dibentuk oleh agar-agar dipengaruhi oleh konsentrasi agaragar, $\mathrm{pH}$, dan kadar gula. Berdasarkan penelitian sebelumnya, spirulina dapat menurunkan derajat keasaman adonan es krim secara signifikan. ${ }^{13}$ Menurunnya $\mathrm{pH}$ es krim dapat mengurangi kekuatan gel yang terbentuk sehingga perlu meningkatkan konsentrasi agar-agar yang digunakan. Selain itu, rendahnya nilai overrun disebabkan karena viskositas adonan meningkat akibat penambahan spirulina yang meningkatkan bahan kering pada adonan. Akibatnya udara sulit bercampur dengan adonan sehingga tekstur es krim menjadi keras.

Melting rate atau kecepatan pelelehan menggambarkan volume es krim yang meleleh pada waktu tertentu ketika berada di suhu ruang. ${ }^{18}$ Secara statistik, tidak ada pengaruh penambahan spirulina terhadap tingkat pelelehan es krim kacang hijau. Es krim kacang hijau memiliki melting rate yang lebih 
rendah dibandingkan es krim kacang hijau kontrol. Melting rate berkaitan dengan nilai overrun. Produk dengan nilai overrun tinggi lebih tahan terhadap pelelehan. Produk es krim yang dihasilkan memiliki kualitas yang cukup baik karena memiliki nilai melting rate yang rendah, sehingga es krim ini tahan terhadap pelelehan.

Es krim perlakuan dengan nilai sifat fisik terbaik adalah es krim kacang hijau dengan penambahan $0.15 \%$ spirulina. Es krim kacang hijau dengan penambahan $0.15 \%$ spirulina memiliki nilai overrun $19.68 \%$ dan melting rate sebesar 0.5 $\mathrm{ml} /$ menit.

\section{Tingkat Penerimaan}

Es krim kacang hijau dengan penambahan $0.15 \%$ dan $0.30 \%$ spirulina mendapatkan nilai warna tertinggi sebesar 3.68. Es krim kacang hijau kontrol memiliki warna hijau pucat. Semakin besar konsentrasi penambahan spirulina, semakin pekat warna hijau pada produk yang dihasilkan. Meskipun secara statistik tidak ada beda nyata es krim dengan penambahan $0.15 \%$ dan $0.30 \%$ spirulina. Warna hijau pada es krim berasal dari pigmen klorofil. Setiap gram spirulina kering mengandung 3,34 mg klorofil a yang merupakan pigmen utama pada spirulina. $^{23}$ Penelitian sebelumnya juga mendapatkan hasil yang sama. ${ }^{13}$

Salah satu karakteristik es krim sebagai makanan beku adalah sedikitnya aroma es krim yang dapat tercium karena tidak terjadi penguapan pada zat dalam es krim. ${ }^{18}$ Penambahan spirulina tidak mempengaruhi nilai aroma es krim kacang hijau. Namun nilai aroma cenderung menurun seiring meningkatnya konsentrasi penambahan spirulina. Es krim kacang hijau kontrol memiliki aroma khas kacang hijau yang disukai oleh panelis. Spirulina memiliki aroma amis yang cukup kuat seiring dengan konsentrasinya yang meningkat.

Tekstur es krim merupakan salah satu indikator bagi kualitas es krim yang baik. Es krim memiliki tekstur yang lembut. Penambahan spirulina tidak mempengaruhi nilai tekstur es krim kacang hijau meskipun nilainya cenderung menurun. Menurunnya nilai tekstur berkaitan dengan rendahnya nilai overrun yang menunjukkan tekstur es krim yang keras karena terbentuknya kristal es yang besar.

Penambahan spirulina menurunkan nilai rasa pada es krim kacang hijau secara signifikan. Penilaian rasa dipengaruhi oleh persepsi akan warna dan aroma. Hasil analisis menunjukkan es krim perlakuan dengan nilai rasa tertinggi adalah es krim kacang hijau dengan penambahan $0.15 \%$ spirulina. Es krim kacang hijau dengan penambahan $0.45 \%$ spirulina memiliki nilai terendah yang masih dapat diterima panelis dalam kategori netral. Es krim kacang hijau tanpa penambahan spirulina memiliki rasa khas kacang hijau. Menurunnya penilaian rasa pada es krim kacang hijau disebabkan karena penambahan spirulina meninggalkan rasa pahit. Rasa 'alga' adalah salah satu penyebab rendahnya penerimaan produk yang mendapat penambahan spirulina. ${ }^{24}$ Hal ini disebabkan karena tingginya kadar zat besi pada spirulina sehingga menimbulkan rasa yang kurang disukai.

Es krim perlakuan dengan tingkat penerimaan terbaik adalah es krim kacang hijau dengan penambahan $0.15 \%$ spirulina. Es krim kacang hijau dengan penambahan $0.15 \%$ spirulina memiliki nilai warna 3.68 , nilai aroma 3.36 , nilai tekstur 3.36, dan nilai rasa 3.28 yang masih disukai panelis.

\section{SIMPULAN}

Penambahan spirulina meningkatkan kadar zat besi dan protein serta mempengaruhi kadar lemak es krim kacang hijau secara signifikan. Penambahan spirulina menurunkan nilai overrun namun tidak mempengaruhi melting rate es krim kacang hijau. Penambahan spirulina mempengaruhi nilai warna dan menurunkan nilai rasa secara signifikan serta menurunkan aroma dan tekstur es krim kacang hijau.

Penambahan $0.15 \%$ spirulina pada es krim kacang hijau merupakan es krim perlakuan yang paling disukai panelis. Es krim ini mengandung $1.465 \mathrm{mg} \%$ zat besi, $1.221 \%$ protein, dan $0.252 \%$ lemak dengan nilai overrun sebesar $19.68 \%$ dan melting rate $0.5 \mathrm{ml} / \mathrm{menit}$.

\section{SARAN}

Perlu dilakukan penelitian lebih lanjut untuk meningkatkan kualitas es krim dengan penambahan spirulina.

\section{DAFTAR PUSTAKA}

1. de Benoist B et al., eds. Worldwide prevalence of anaemia 1993-2005. WHO Global Database on Anaemia Geneva, World Health Organization, 2008.

2. Departemen Kesehatan Republik Indonesia. Laporan Hasil Riset Kesehatan Dasar (RISKESDAS) Indonesia tahun 2013. Jakarta : Badan Penelitian dan Pengembangan Kesehatan 2013

3. Kartamihardja, Emmy. Anemia Defisiensi Besi. Fakultas Kedoteran Universitas Wijaya Kusuma Surabaya. 2008

4. Sachdev H, Gera T, Nestel P. Effect of Iron Supplement on Mental and Motor Development in 
Children: Systematic Review of Randomized Controlled Trial. Public Health Nutr 2005;8:117-32

5. lozoff B, Georgieff M K. Iron Deficiency And Brain Development. Semin Pediatr Neurol 2006 13:158165.

6. Haas JD, Brownlie $\mathrm{T}$ 4th. Iron deficiency and reduced work capacity: a critical review of the research to determine a causal relationship. J Nutr. 2001 Feb; 131(2S-2):676S-688S, discussion 688S$690 \mathrm{~S}$

7. Fitrahdini. Suwarman U. Nurmalina R. Analisis Persepsi Konsumen Terhadap Ekuitas Merek Produk Es Krim. Jur Ulm Kel Dan Kons Januari 2010. p 74-81. vol 3 no 1. ISSN 1907-037)

8. Mien K. Mahmud, Hermana, Nils Aria Zulianto, Rossi Rozana, Apriyantono, dkk. Tabel Komposisi Pangan Indonesia (TKPI). Jakarta: Elex Media Komputindo; 2008

9. US FDA. Notice to US Food and Drug Administration that the use of Certified Organic Spirulina (Arthrospira platensis) is Generally Recognized as Safe. July 12th, 2011

10. Agricultural Research Service USDA. National Nutrient Database for Standard Reference Release 26 Basic Report 1166, Seaweed, spirulina, dried. Diakses tanggal 21 April 2014 dari http://ndb.nal.usda.gov/ndb/foods/show/3353

11. Robert Henrikson. Earthfood Spirulina. Ronore Enterprises Inc. 2009.

12. ME Gershwin, Amha B, editors. Spirulina in human nutrition and health. New York. CRC Press. 2008.

13. Malik P, Kempanna C, Paul A. Quality Characteristics of Ice Cream Enriched with Spirulina Powders. International Journal of Food and Nutritional Sciences. Vol 2 Iss 1, Jan-Mar 2013

14. Mubarak AE. Nutritional Composition and Antinutritional Factors of Mung Bean Seeds. Food Chemistry 89 (2005) 489-495

15. Kanetro, Hastuti. Ragam Produk Olahan KacangKacangan. Yogyakarta. Unwama Press. 2006. P. 44-45

16. Etika B. Kiran B. Effect of Household Prcessing on The In Vitro Bioavailability of Iron In Mungbean. Food And Nutrition Bulletin, Vol 28, No. 1. 2007. $18-22$

17. Rohman, Abdul. Analisis Komponen Makanan. Yogyakarta.Graha Ilmu. 2013

18. Clark C. The Science of Ice Cream. Cambrigde. 2004

19. Institute of Medicine. Food and Nutrition Board. Dietary Reference Intakes for Vitamin A, Vitamin K, Arsenic, Boron, Chromium, Copper, Iodine, Iron, Manganese, Molybdenum, Nickel, Silicon, Vanadium, and Zinc : a Report of the Panel on Micronutrients . Washington, DC: National Academy Press; 2001

20. Dewan Standarisasi Nasional (DSN), Standar Nasional Indonesia (SNI) 01-3713-1995 Tentang Es Krim. Jakarta. Departemen Perindustrian Dan Perdagangan Republik Indonesia. 1995
21. Kusnandar, Feri. Kimia pangan komponen makro. Dian Rakyat. Jakarta. 2010

22. Arun K. Ramesh C. Chandan. Ice Cream and Frozen Dessert. In : Yui YH, editor. Handbook of Food Product Manufacturing. 2nd edition. John Willey and Sons inc. 2007.

23. Soedjati, Sri. Profil Pigmen Polar dan Non Polar Mikroalga Spirulina Sp dan Potensinya Sebagai Pewarna Alami. Ilmu kelautan September 2012. Vol 17. (3) 176-181

24. Metin G, Reyhan I. Influence of Spirulina Plantesis Powder on The Microflora of Yoghurt and Acidophilus Milk. Mljekarstvo 60 (4), 237-243 (2010) 